\title{
Contributing factors to the failure of an unusually large landslide triggered by the 2014 Ludian, Yunnan, China, $M_{\mathrm{s}}=6.5$ earthquake
}

\author{
Z. F. Chang ${ }^{1}$, X. L. Chen ${ }^{2}$, X. W. An ${ }^{1}$, and J. W. Cui ${ }^{1}$ \\ ${ }^{1}$ Earthquake Administration of Yunnan Province, Kunming 650041, China \\ ${ }^{2}$ Key Lab of Active Tectonics and Volcano, Institute of Geology, China Earthquake Administration, Beijing 100029, China
}

Correspondence to: X. L. Chen (04chxl@sina.com)

Received: 24 November 2014 - Published in Nat. Hazards Earth Syst. Sci. Discuss.: 13 January 2015

Revised: 22 January 2016 - Accepted: 24 January 2016 - Published: 19 February 2016

\begin{abstract}
The 3 August 2014 Ludian, China, $M_{\mathrm{S}}=6.5$ earthquake caused many large landslides. The biggest occurred at Hongshiyan near the epicenter, had a volume of $1.0 \times 10^{7} \mathrm{~m}^{3}$ and dammed the Niulanjiang River, creating a large lake. Post-event field investigations yielded detailed data on the following aspects: rock structure of the landslide, the local lithology and geometry of the area around the landslide dam and composition and grain sizes of the debris avalanche. Based on these data, this work analyzes the geology and topography of the Hongshiyan area, and explores reasons for the occurrence of an unusually large landslide at this location. Our analysis suggests the following conditions are responsible for this catastrophic event. (1) Due to recent crustal deformation, intense incision on the river increased topographic relief with steep slopes and scarps. (2) Combined structures, including unloading fissures, high-angle joints and low-angle beds along the river, as well as an upperstrong and lower-weak interlayer structure on the slope, especially the existence of weak layers in the slope, are important factors that contribute to this large failure. (3) Hongshiyan lies near an active fault, where intense crustal deformation has resulted in rock fractures and weathering, and frequent earthquakes may progressively reduce the strength of the slope. (4) During the $M_{\mathrm{S}}=6.5$ earthquake, the terrain and site conditions led to abnormally strong ground shaking. The combined impacts of these factors triggered a very large landslide during a moderate-sized earthquake.
\end{abstract}

\section{Introduction}

At 16:30 LT (local time) on 3 August 2014, an earthquake of magnitude $M_{\mathrm{s}}=6.5$ struck the county of Ludian, Yunnan, southwest China. The epicenter was located at $27.10^{\circ} \mathrm{N}-$ $103.33^{\circ} \mathrm{E}$, in the town of Longtoushan in this county, with a focal depth of $12 \mathrm{~km}$ (China Earthquake Administration, 2014). This event was felt in more than 10 cities or counties in Yunnan, Sichuan, and Guizhou provinces, with intensity IX in the meizoseismal area. As of 8 August 2014, the death toll from the earthquake had reached 617 people, with 112 people missing (China Earthquake Administration, 2014).

This shock occurred in a rugged mountainous area, which resulted in large landslides including rockfalls, avalanches and debris flows. Field investigations show that the sizes of these landslides ranged from thousands to millions of cubic meters. In particular, a huge landslide was created at Hongshiyan, on the right bank of the Niulanjiang River in the southern most heavily affected region. Coupled with an old landside on the left bank, this new avalanche body clogged the Niulanjiang River, creating a $120 \mathrm{~m}$ high, $1.0 \times 10^{7} \mathrm{~m}^{3}$ dam, which raised the river level $30 \mathrm{~m}$ and increased the surface area upstream of the dam to 3 times that of normal. This increased risk to residents and hydropower stations both upstream and downstream of the landslide dam.

Although earthquake-induced landslides are common in southwest China, it is seldom that a moderate quake like the 2014 Ludian $M_{\mathrm{S}}=6.5$ produces such a large landslide. The objective of this paper is to describe this unusual event. Our analysis is based on the data from field observations, and focuses on the geological conditions of the Hongshiyan area. 


\section{Geological setting}

The Ludian $M_{\mathrm{S}}=6.5$ event took place in the northeastern Chinese province of Yunnan, tectonically in the SichuanYunnan block (Fig. 1). This area is characterized by intense neotectonic movements, numerous active faults and frequent major earthquakes (Allen et al., 1989; Song et al., 2002; Zhang et al., 2004; Xu et al., 2003; Guo et al., 2013). Field investigations after the Ludian earthquake suggested that the Ludian quake was generated by the southwest segment of the Zhaotong-Lianfeng fault zone that lies on the east flank of the Sichuan-Yunnan block (Fig. 1). This fault zone consists of two faults: the Lianfeng fault and Zhaotong-Ludian fault, dominated by thrusting with a right-slip component (Wen et al., 2013), which serve as the southern boundary of the secondary active Daliangshan block (Fig. 1). In this block, there is also the nearly northerly trending Daliangshan fault - (3) in Fig. 1 - dominated by a left slip with thrusting motion (Shen and Xu, 2000; Zhou et al., 2003; Zhang et al., 2005; He et al., 2008). Since Cenozoic times, the neotectonic movement in the Daliangshan block has been expressed by a left slip and thrust on the Daliangshan fault, as well as shortening of nearly NS-trending folds, which is about $10.9 \pm 1.6 \mathrm{~km}$ (Chen and He, 2008). The Zhaotong-Lianfeng fault lies at the southeast edge of the Daliangshan block, accommodating the southeastward motion of this block ( $\mathrm{Li}$ and Wang, 1975, Li, 1993; Kan et al., 1977; Tapponnier et al., 1986; Armijo et al., 1989; Zhong and Ding, 1996; Zhang et al., 2003; Xu et al., 2003). Near the epicenter of the Ludian event are major branches of the Zhaotong-Lianfeng fault zone: the Zhaotong-Ludian fault and the NW-trending Xiaohe fault (Fig. 2). The Zhaotong-Ludian fault comprises three NE striking faults, from east to west which are the ZhaotongLudian fault - (2) on Fig. 1; Z. L. F. on Fig. 2 -, Sayuhe fault (S. Y. H. F. on Fig. 2) and the Longshu fault (L. S. F. on Fig. 2). These faults show a complicated structure in this area, where NE- and NW-trending faults intersect each other, although the NE ones dominate. The historical records show that 15 moderate and major events have taken place around the Zhaotong-Ludian fault since 1885 (Fig. 2), such as the following: 1948 Yiliang $M_{\mathrm{S}}=5.8,1974$ Daguan $M_{\mathrm{s}}=7.1$, 2004 Ludian $M_{\mathrm{S}}=5.6,2006$ Yanjin $M_{\mathrm{s}}=5.1,2012$ Yiliang $M_{\mathrm{S}}=5.6$ and $M_{\mathrm{S}}=5.7$ and the event under investigation, $\mathrm{Lu}-$ dian $M_{\mathrm{S}}=6.5$ (Li and Wang, 1975; Song et al., 2002; Zhang et al., 2005; Wei et al., 2012; Division of Earthquake Prevention and Disaster Reduction, China Earthquake Administration, 1995).

With the exception of the Cretaceous period, strata from the Sinian through to the Quaternary are exposed in the Ludian area (Fig. 2, Table 1). The pre-Mesozoic formations are most widely distributed, and are dominated by sandstone, shale, limestone and dolomite, containing many joints and fissures. Mesozoic strata are present in the northeast and southeast of the seismic area, as continental debris accumulation dominated by sandstone and mudstone. The few Ceno-

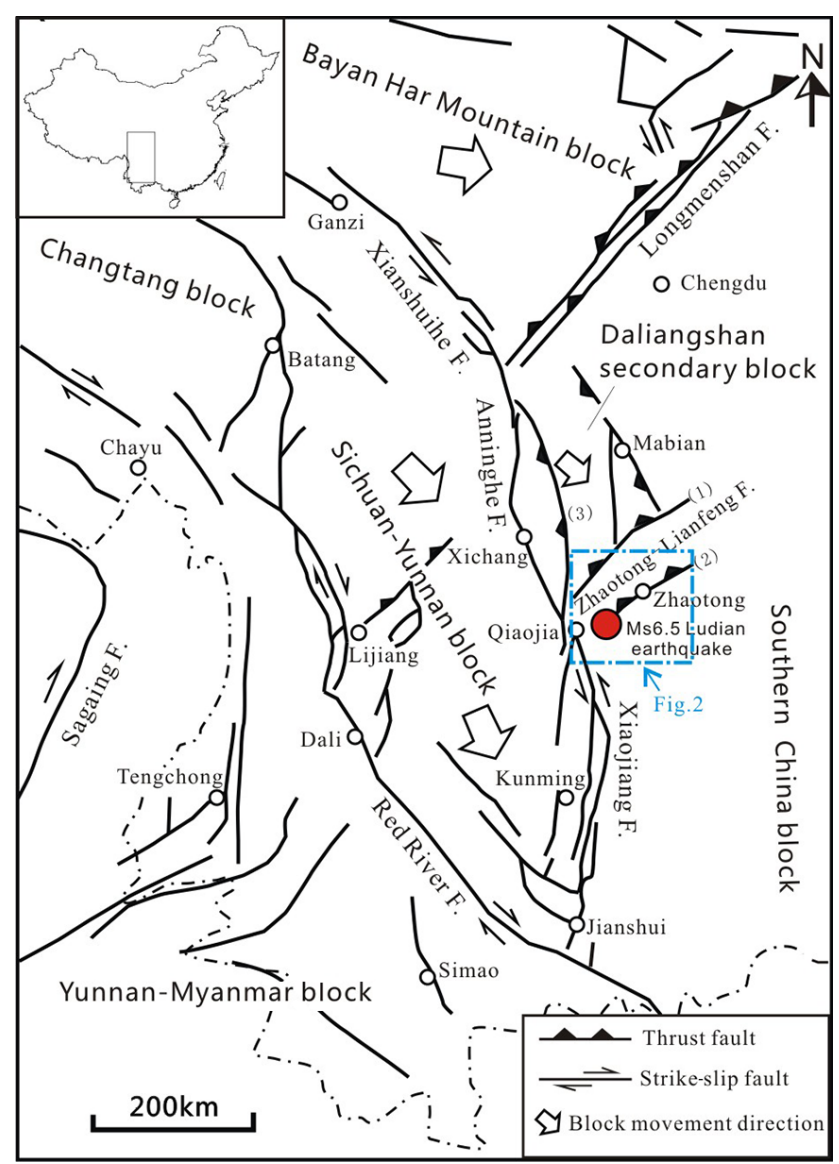

Figure 1. Sketch map showing tectonic setting of the 2014 Ludian $M_{\mathrm{s}}=6.5$ earthquake.

zoic strata are scattered in the intermountain basins, such as the Ludian basin, which are made up of fluviolacustrine clay rock and sandy gravel (Fig. 2, Table 1).

Geographically, the Ludian seismic area is situated in the northeastern Yunnan-Guizhou plateau. Before Miocene times, it was a relatively intact and uniform peneplain. Since the end of the Miocene, due to many tectonic movements, this area has been uplifted and eroded. Consequently, the original peneplain was reformed into steep mountainous landscape with many intermountain lowlands (basins). As a major river in southwest China, the Niulanjiang River flows from southeast to northwest through the Ludian seismic area. Incision depths of up to $1200-3300 \mathrm{~m}$ form V-shaped valleys. On either bank of this river, the slopes are usually very steep. In the epicentral area of the 2014 Ludian earthquake, $80 \%$ of the slopes steeper than $40^{\circ}$ are located along the banks of the Niulanjiang River and its tributaries south of the epicenter (Fig. 3); while in the north and east of the seismic area, the terrain is relatively gentle, dominated by middle-height and low hills, with steepness generally less than $20^{\circ}$ (Fig. 3). 
Table 1. Strata and lithology of the study area.

\begin{tabular}{|c|c|}
\hline Stratum & Lithology \\
\hline Quaternary (Q) & Gray and brown gravel, clay, sand and silt loam, $25-80 \mathrm{~m}$ thick \\
\hline Neogene $(\mathrm{N})$ & $\begin{array}{l}\text { Gray-white and gray-green conglomerate, clay rock intercalated with } \\
\text { lignite beds, semi-consolidated, } 180-366 \mathrm{~m} \text { thick }\end{array}$ \\
\hline Jurassic $(J)$ & $\begin{array}{l}\text { Brown-red and purple-gray medium-thick-bedded mudstone, siltstone } \\
\text { with marl, 366-1000 m }\end{array}$ \\
\hline Triassic $(\mathrm{T})$ & $\begin{array}{l}\text { Purple and yellow-green medium-thick-bedded siltstone, silty } \\
\text { mudstone, 352-726 m thick }\end{array}$ \\
\hline Permian $(\mathrm{P})$ & $\begin{array}{l}\text { Lower: gray, dark-gray, and gray-white thick-bedded or massive limestone } \\
\text { intercalated with a few dolomitic limestone; upper: basalt } \\
\text { total thickness } 1038-1675 \mathrm{~m}\end{array}$ \\
\hline Carboniferous $(\mathrm{C})$ & $\begin{array}{l}\text { Gray-white thick-bedded limestone, dolostone, biological debris limestone } \\
\text { and oolitic limestone intercalated with dolomitic limestone; sandy shale } \\
\text { and coal-bearing beds in the lower portion, total thickness } 2500 \mathrm{~m}\end{array}$ \\
\hline Devonian (D) & $\begin{array}{l}\text { Lower: green-gray medium-thick beds of quartz sandstone, siltstone with } \\
\text { argillaceous shale; middle; upper: gray thick-bedded argillaceous } \\
\text { limestone, dolomite, limestone with mudstone, } 219-742 \mathrm{~m} \text { thick }\end{array}$ \\
\hline Silurian (S) & $\begin{array}{l}\text { Gray-black and dark brown thin to medium thick shale, limestone and } \\
\text { sandstone, } 530 \mathrm{~m} \text { thick }\end{array}$ \\
\hline Ordovician $(\mathrm{O})$ & $\begin{array}{l}\text { Gray-green and brown-red shale intercalated with thin beds of sandstone, } \\
\text { yellow-brown moderately thick- and thin-bedded argillaceous sandstone } \\
\text { and dolomite, } 970 \mathrm{~m} \text { thick }\end{array}$ \\
\hline Cambrian $(\epsilon)$ & $\begin{array}{l}\text { Gray-white and gray-green thin-bedded siltstone, dark-gray massive } \\
\text { dolomite, limestone, argillaceous dolomite, hundreds to thousands of meters thick }\end{array}$ \\
\hline Sinian $(\mathrm{Z})$ & $\begin{array}{l}\text { Purple-gray thick-bedded quartz sandstone, gray thick-bedded dolomite } \\
\text { and gray-purple thin-bedded phyllite, more than } 1000 \mathrm{~m} \text { thick }\end{array}$ \\
\hline
\end{tabular}

\section{Landslide dam at Hongshiyan}

The Ludian $M_{\mathrm{S}}=6.5$ earthquake triggered a very large landside on the right bank of the Niulanjiang River near the Hongshiyan village $\left(27.035^{\circ} \mathrm{N}-103.397^{\circ} \mathrm{E}\right)$. The earthquake also partly reactivated an old landslide on the opposite left bank. Both landslides combined to produce a barrier that dammed the river, resulting in a lake (Fig. 4).

\subsection{Geometry and composition of the landslide dam}

The landslide at Hongshiyan dams the V-shaped valley of the Niulanjiang River. It is $1000 \mathrm{~m}$ long and $270 \mathrm{~m}$ wide, with a surface area of $2.8 \times 10^{5} \mathrm{~m}^{2}$. The elevation is $1216 \mathrm{~m}$ at the dam top, and $1110 \mathrm{~m}$ at the dam base, with the maximum height of the dam $120 \mathrm{~m}$ above river level (Fig. 5). The total volume of the dam is estimated to be about $1.0 \times 10^{7} \mathrm{~m}^{3}$ (Institute for Earthquake Engineering Survey of Yunnan Province, 2014).

Overall, the dam top is higher on the right bank and lower on the left bank, and the maximum heights are $1349 \mathrm{~m}$ on the right bank and $1270 \mathrm{~m}$ on the left, respectively. Upstream the dam slope is relatively steep with an average slope ratio of $1: 2.5$; while downstream the dam slope is less steep with an average slope ratio of $1: 5.5$ (Figs. 5 and 6).

Field investigation shows that this landslide dam was the result of a rapid avalanche. The primary source of the avalanche debris was from high up on the right bank of the river, and partly from the old landslide on the left bank (Fig. 6). Pebbles dominate the dam, which are weakly weathered or fresh dolomitic limestone and dolomite with a maximum grain size of over $5 \mathrm{~m}$. In the dam, the pebbles with sizes exceeding $50 \mathrm{~cm}$ account for $50 \%, 20-50 \mathrm{~cm}$ for $35 \%$ and less than $2 \mathrm{~cm}$ for $15 \%$ of the total, respectively (Institute of Earthquake Engineering of Yunnan Province, 2014).

\subsection{Old landslide on the left bank}

The old landslide lies on the southern side of the landslide dam (Fig. 6). It is $1200 \mathrm{~m}$ wide at the base, $900 \mathrm{~m}$ from the top to the bottom, with an average thickness of $70 \mathrm{~m}$ and a volume of $5.67 \times 10^{7} \mathrm{~m}^{3}$ (Fig. 7). The upper slopes are steep 


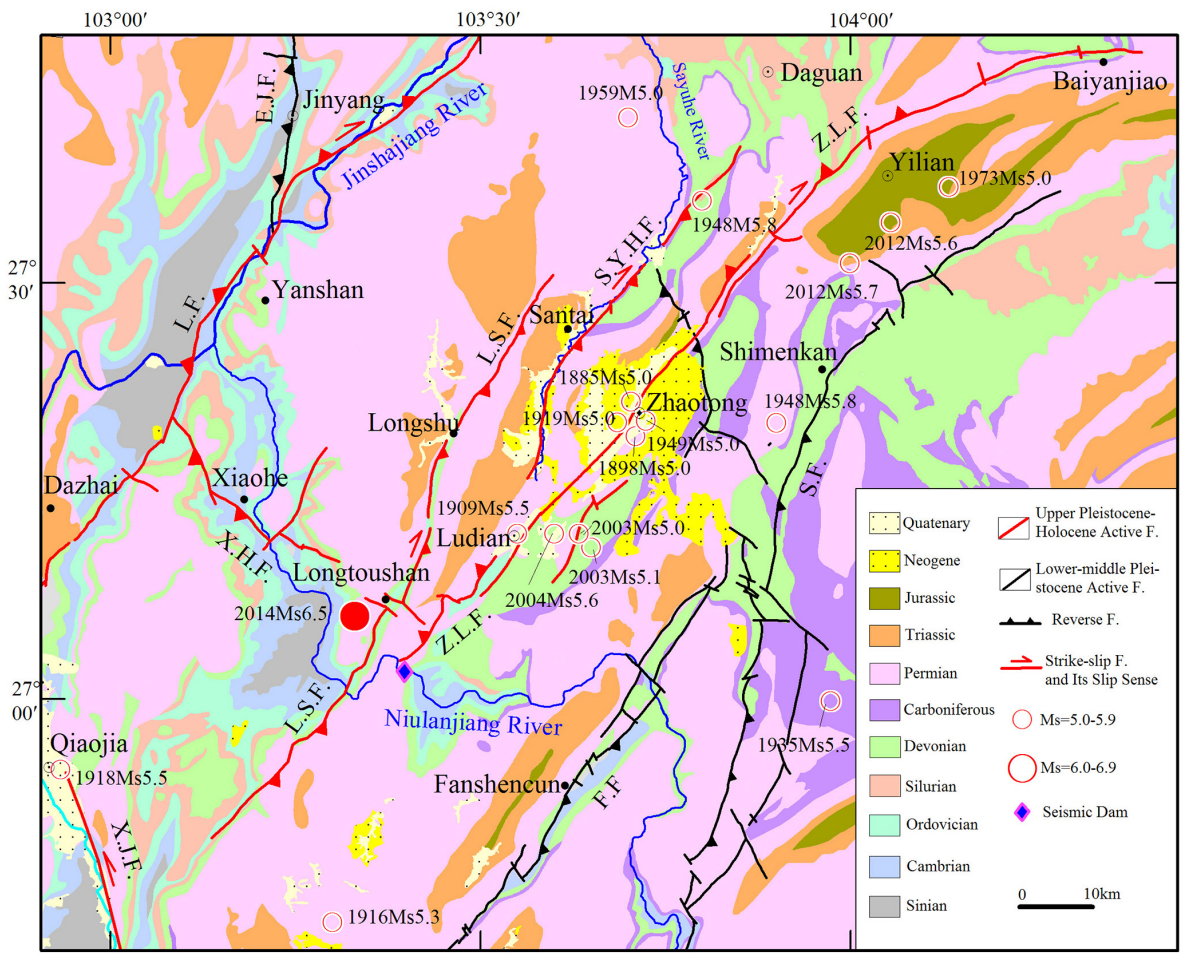

Figure 2. Geological map of the Ludian seismic area (modified from Geological and Mineral Bureau of Yunnan Province, 1990).

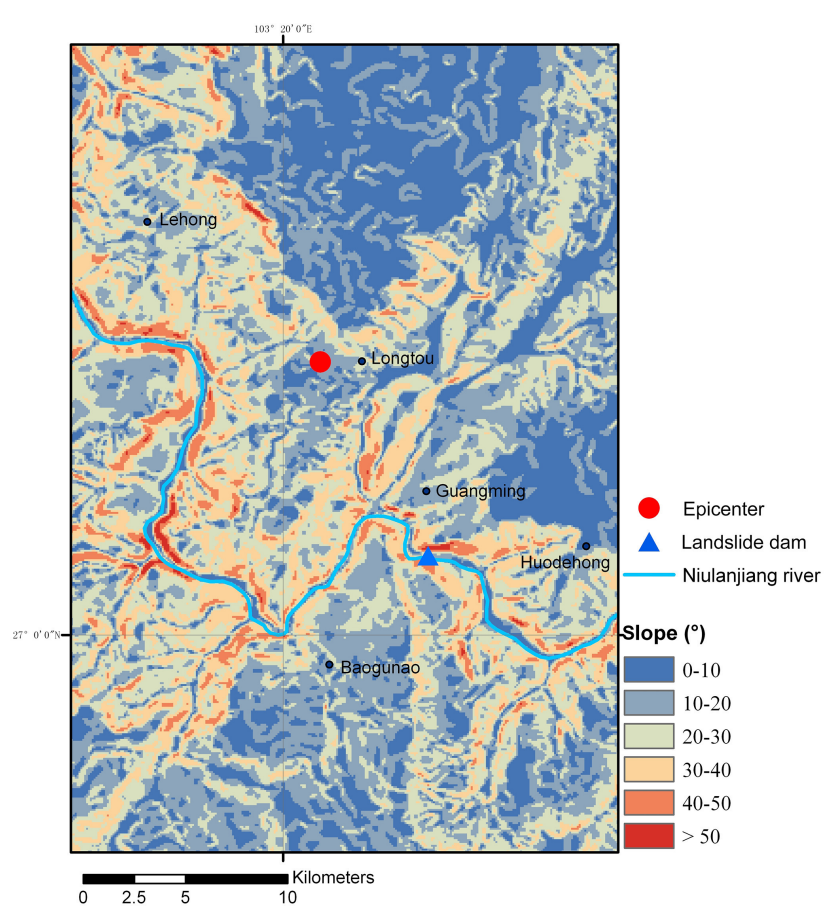

Figure 3. Map showing slope angles in the Ludian area.

and the lower slopes are gentle, with slope angles of 36 and $18^{\circ}$ above and below an elevation of $1400 \mathrm{~m}$, respectively. Drilling data reveals $25-40 \mathrm{~m}$ of infill in the river bed, of

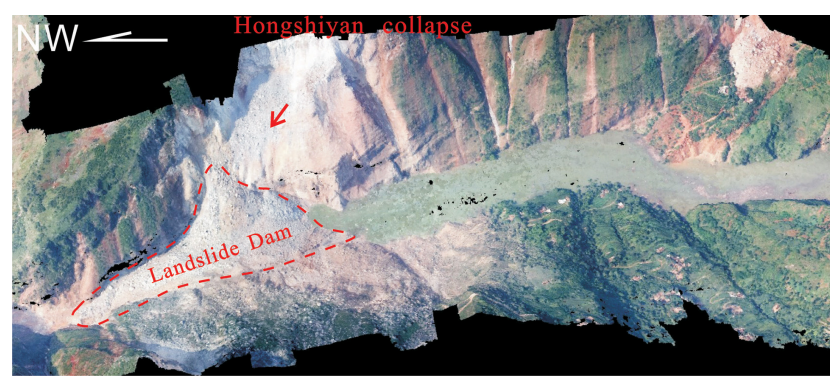

Figure 4. Unmanned aerial vehicle photo showing the landslide dam on the Niulanjiang River. (Image provided by the Institute of Geophysics, China Earthquake Administration. The strata dip is 15$30^{\circ}$.)

which silt is $18-24 \mathrm{~m}$ thick, presumably the deposition of an ancient dammed lake caused by a paleoearthquake. Because the front of this old landside was deposited on the original river bed, the right bank has been eroded by the river, which might make failure more likely.

The rear scarp of the old landslide, which is $300 \mathrm{~m}$ high (elevations of rear and frontal edges are 1850 and $1550 \mathrm{~m}$, respectively), suffered from local collapse (red dashed line in Fig. 7) during the 2014 Ludian $M_{\mathrm{S}}=6.5$ quake, and part of its front slipped into the river (yellow dashed line in Fig. 7). Meanwhile, the surface layer of this old landslide became loose, causing big boulders (the largest is up to $5 \mathrm{~m}$ in diameter) and pebbles to slide into the river, which joined the 


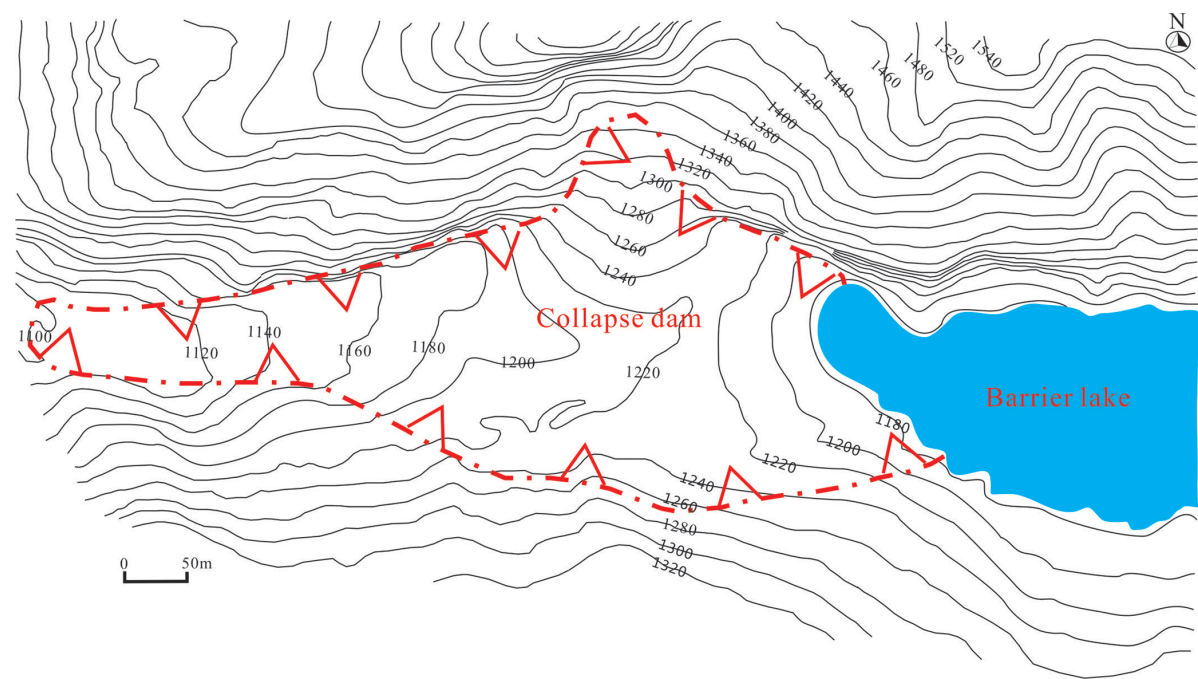

Figure 5. Plan of the landslide dam on the Niulanjiang River at Hongshiyan. Contours are elevations above sea level (modified from Institute for Earthquake Engineering Survey of Yunnan Province, 2014).

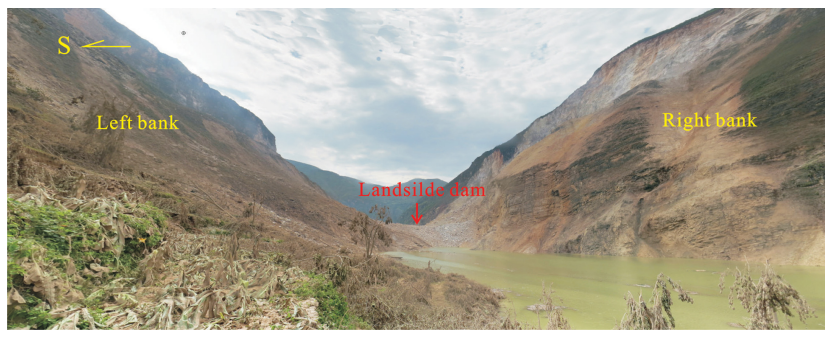

Figure 6. Overall look of the landslide dam at Hongshiyan (view toward west).

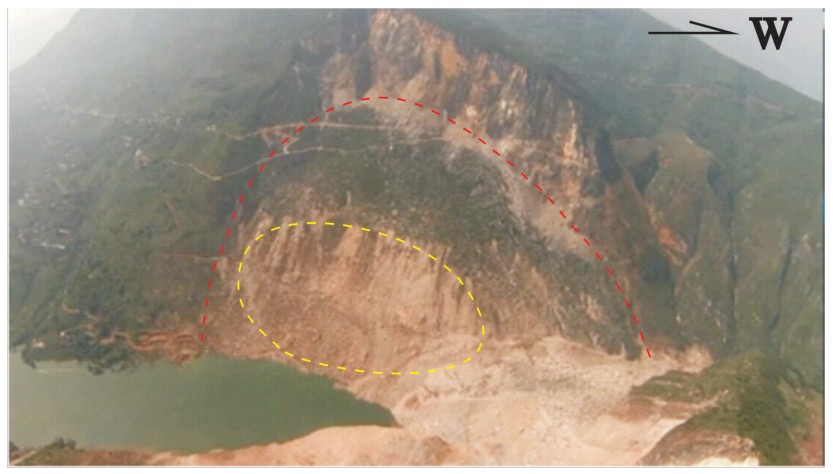

Figure 7. Photo showing the old landslide on the left bank of the Niulanjiang River. Red dashed line denotes old landslide. Yellow dashed line shows the frontal part that collapsed during the $2014 \mathrm{Lu}-$ dian event (view toward south).

avalanche from the right bank to create the dam on the river. Nevertheless, the main body of this old landslide remained relatively stable during the shock, except for cracks on its surface.

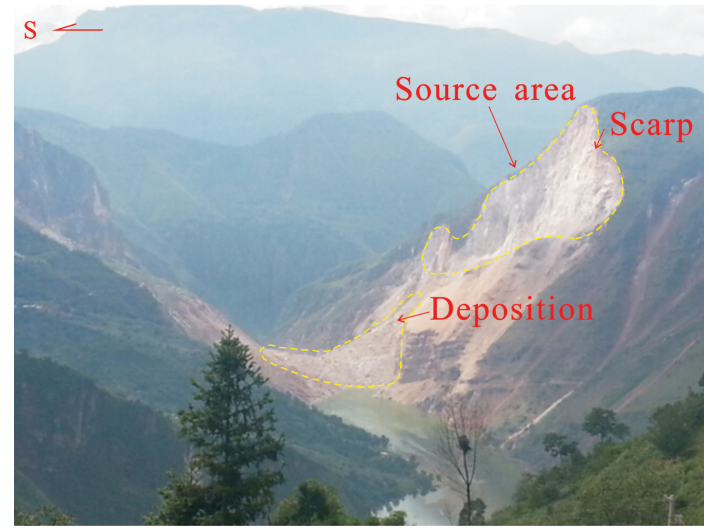

Figure 8. New landslide induced by the 2014 Ludian quake on the right bank of the Niulanjiang River at Hongshiyan (view toward west).

\subsection{New landslide on the right bank}

The avalanche on the right bank of the Niulanjiang River triggered by the 2014 Ludian earthquake is the primary source of the debris forming the landslide dam at Hongshiyan. Its source is at an elevation of $1680 \mathrm{~m}$. The source area is $890 \mathrm{~m}$ long and the highest rear scarp is up to $500 \mathrm{~m}$ (Fig. 8). The total volume is estimated at about $1.0 \times 10^{7} \mathrm{~m}^{3}$. Field investigations indicate that the avalanche consists of mediumbedded dolomitic limestone and dolostone intercalated with sandstone and shale of Ordovician, Silurian, Devonian and Permian systems. These rocks are laced with numerous joints and fissures. In particular, unloading cracks and broken rocks characterize the upper part of the slope. Detailed descriptions of this landslide are in the next section. 


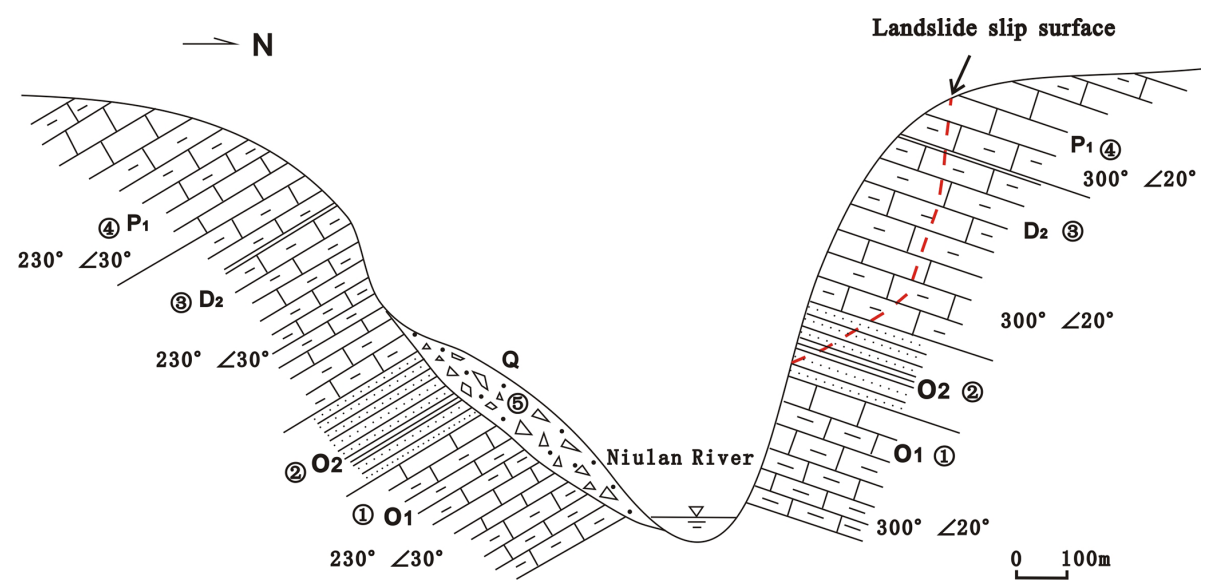

Figure 9. Cross section of the dammed lake before the 2014 Ludian quake. (1) Dolomite and limestone of lower Ordovician. (2) Sandstone with shale and mudstone of middle Ordovician. (3) Dolomite and limestone with argillite of middle Devonian. (4) Massive limestone and dolomite of lower Permian. (5) Quaternary diluvium deposit

\section{New large landslide at Hongshiyan}

\subsection{Geological environment}

As stated previously, the Ludian seismic area lies between the Sichuan-Yunnan block and Daliangshan block (Fig. 1). The Hongshiyan landslide dam is near the Zhaotong-Ludian fault zone that consists of many NE- and NW-trending faults dominated by thrusting, with a right-slip component (Fig. 2). Influenced by the intense fault activity, fractured rock and strongly weathered surfaces characterize this region, particularly along faults or compressive fracture zones. Thickness of the weathering layer is controlled by lithology and topography. In general, dolomite, limestone, quartz-sandstone and siltstone have greater resistance to weathering, while shale and argillaceous rocks are more vulnerable to weathering. On the ridges and gentle slopes, weathering depths are greater than in cols, gullies and steep slopes, where they are relatively thin. Previous data and the field investigations after the 2014 Ludian $M_{\mathrm{S}}=6.5$ quake reveal that the weathering reaches depths $20-25 \mathrm{~m}$ beneath the surface on either bank of the Niulanjiang River in the vicinity of Hongshiyan. The depth of weathering perpendicular to the slope is 20 $25 \mathrm{~m}$ on the right bank and $25-30 \mathrm{~m}$ on the left bank, respectively. In particular, the limestone and dolomite have intense dissolution-erosion weathering as deep as $20 \mathrm{~m}$, and weak dissolution-erosion weathering affects to a depth $60 \mathrm{~m}$. These intense weathering effects provide weakened source material for large landslides.

\subsection{Structure of rock}

On either bank of the river around the landslide dam, rocks strike in different directions. On the right bank, rock attitudes are $20-30^{\circ} \mathrm{NW} / 15-30^{\circ} \mathrm{SW}$; and on the left bank, rocks dip downstream with attitudes $20-60^{\circ} \mathrm{NE} / 10-30^{\circ} \mathrm{NW}$ (Fig. 9).

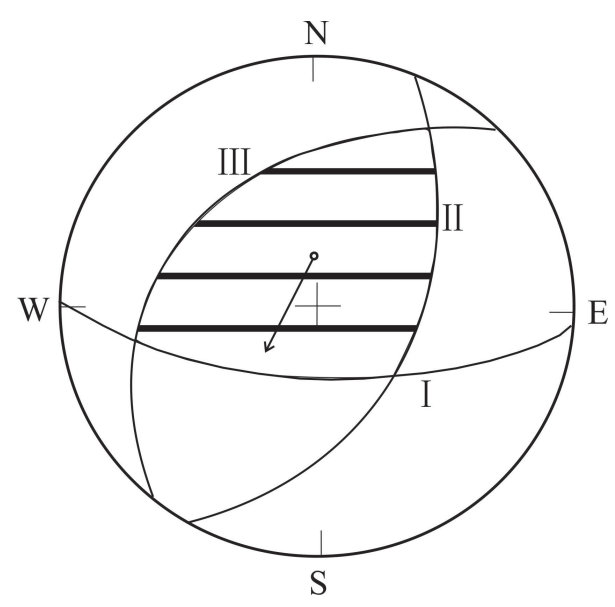

Figure 10. Wolf projection of joints in individual avalanches at Hongshiyan (projection of lower hemisphere). I: steep joint parallel to river, II: steep joint at a normal angle to the river, III: interbed joint (see Table 2).

Because of various long-term geological effects, gentle folds or flexures characterize strata in this area. On either bank of the river, steeply dipping unloading fissures are developed well into the rocks, which have relatively flat surfaces, generally opening $1-2 \mathrm{~cm}$. Most of these fissures have no filling, or are partly filled by calcareous or silt material. In situ observations found three sets of joints in rock on the slope, i.e. steep joints at normal angles to the river, joints parallel to the river, and interbed joints (Table 2).

We use the projection on the equator plane of the WolfNet to describe the structure of the rock on the slope around the landslide (Fig. 10). It can be assumed that the steep joint at a normal angle to the river (I) and that which is parallel to the river (II) cut the rock body into a small mass. In addition to the gentle dipping joint (III), they will generate an unstable 
Table 2. Features of rock joints in the landslide body at Hongshiyan (after Institute for Earthquake Engineering Survey of Yunnan Province, 2014).

\begin{tabular}{lcll}
\hline Joint & Code & $\begin{array}{l}\text { Attitude } \\
\text { (strike/dip } \\
\text { direction/ } \\
\text { dip angle) }\end{array}$ & Description \\
\hline Normal angle to river & I & $30^{\circ} \mathrm{NW} / 80^{\circ} \mathrm{NE}$ & Mostly open, as wide solution fissures on surface filled with secondary mud \\
\hline Parallel to river & II & $3^{\circ} \mathrm{EW} / 80-83^{\circ} \mathrm{S}$ & $\begin{array}{l}\text { Affected by unloading rebound, open at shallow depth, with fluctuating; } \\
\text { rough surface and large extension }\end{array}$ \\
\hline Interbed & III & $20-60^{\circ} \mathrm{NE} / 10-30^{\circ} \mathrm{NW}$ & $\begin{array}{l}\text { Downstream gentle dip, mostly closed, large extension, locally as mud } \\
\text { interbed, primarily developed in thin-bedded and medium-bedded sandy } \\
\text { mudstone of the Ordovician period }\end{array}$ \\
\hline
\end{tabular}

block (shaded area in Fig. 10). Under seismic shaking, this block is prone to slip toward the open side of the slope (along river flow) (arrow in Fig. 10).

At this site, the upper portion of the slope is dolomite that is relatively strong, while sandy mudstone and shale constitute the lower portion and are relatively weak (Figs. 9 and 11). In natural conditions, the brittle rock in the upper portion of the slope is prone to fracturing, while the weak rock in the lower portion of the slope deforms plastically. Under seismic shaking, this weak rock would be compressed, inducing instability in the rock of the upper portion, and becoming a potential sliding surface. The weak rock in the lower portion has many cracks and joints present. The weak layer served as the slip surface during the landsliding (Fig. 11).

\subsection{Landscape and relief condition}

Near the village of Hongshiyan where the largest seismic landslide occurred, the Niulanjiang River runs through a deep and steep valley with topographic relief of $800-1000 \mathrm{~m}$. On the left bank, slope angles are $35-50^{\circ}$, and the slope height near the riverbed is $200-220 \mathrm{~m}$. On the right bank, slope angles are $35-50^{\circ}$, locally up to $70^{\circ}$ or more; the slope is $800 \mathrm{~m}$ high near the riverbed (Figs. 3, 7 and 8). Such topography provides an opportunity for very large landslides where the geology, rock mass properties and rock mass defects combine to create a vulnerable slope.

\subsection{Seismic acceleration}

Although the 2014 Ludian earthquake is a moderate-sized event, the Longtoushan seismic station near the epicenter recorded high acceleration values of ground motion. The peak ground accelerations of NS, EW and vertical components are $948.5 \mathrm{Gal}, 704.9 \mathrm{Gal}$ and $503.8 \mathrm{Gal}$, respectively (Fig. 12). The intensity of the most heavily affected area is IX degree according to the Chinese seismic intensity scale (Seismic Intensity Zoning Group et al., 1990).

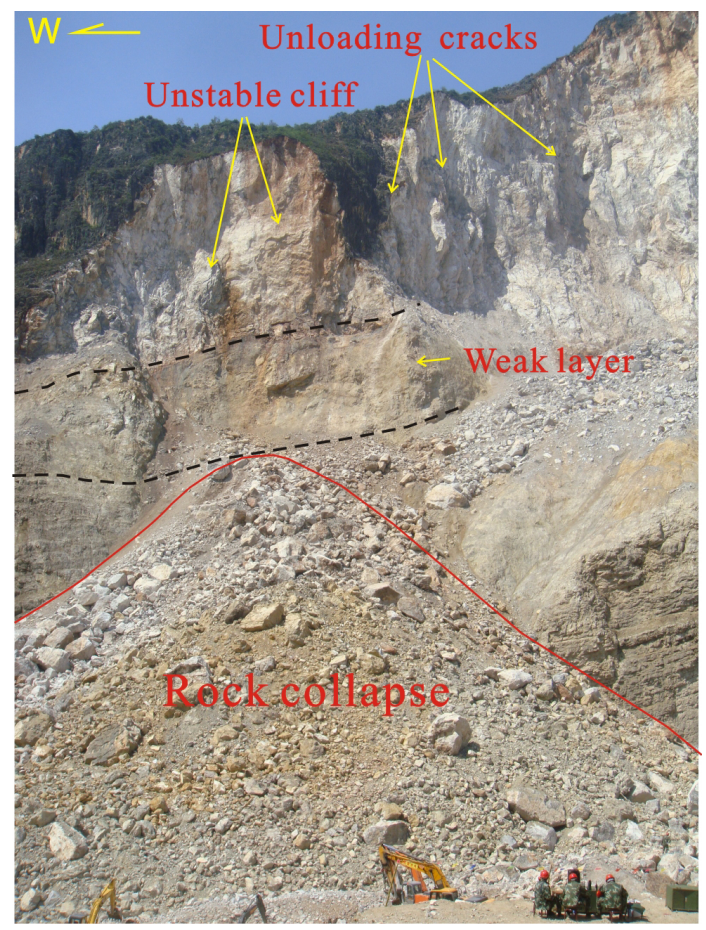

Figure 11. Rock structure that unleashed the rock avalanche at Hongshiyan during the Ludian earthquake.

Meunier et al. (2007) found that seismic landslides are more likely to occur closer to the top of a mountain ridge, and when the slopes face away from the epicenter it can amplify the seismic acceleration. The Hongshiyan landslide is $10 \mathrm{~km}$ from the epicenter. It is on the slope that faces away from the epicenter of the Ludian quake, and the avalanche source area is on the upper half of the mountain slope (Fig. 8). Topographic amplification of strong ground shaking likely contributed to the formation of the very large landslide at Hongshiyan. 


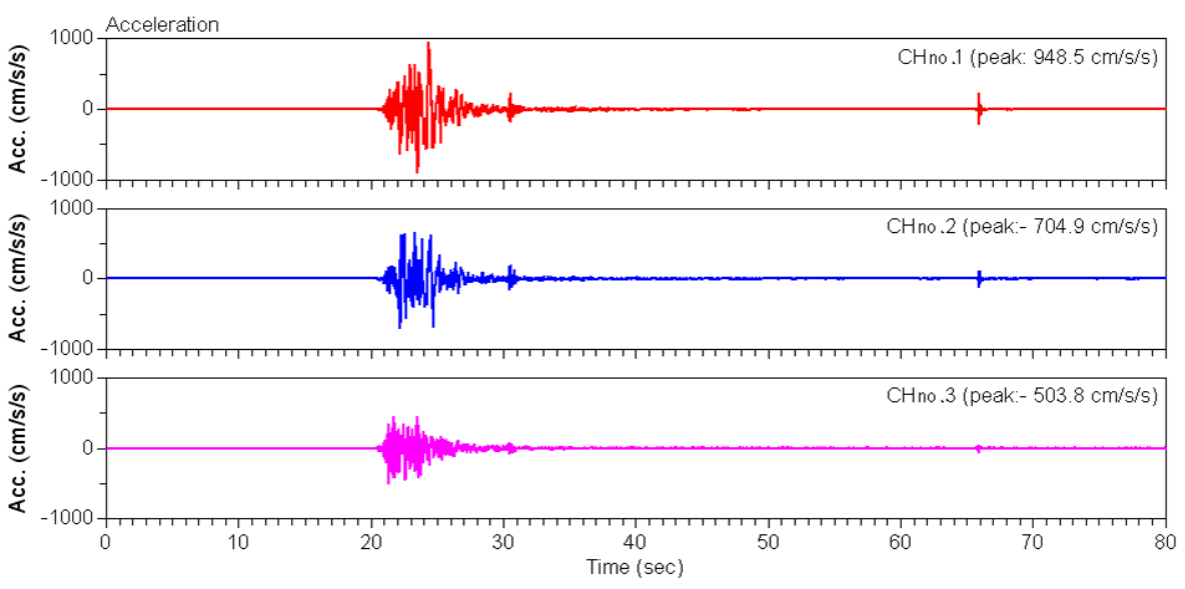

Figure 12. Peak ground accelerations recorded by the Longtoushan seismic station during the 2014 Ludian $M_{\mathrm{S}}=6.5$ earthquake. Red: EW component, blue: NS component, pink: vertical component.

\subsection{Unloading rock fissures}

Under extensional stress, numerous unloading fissures have developed in the rock of the slopes along the valley of the Niulanjiang River near Hongshiyan. Both banks of the river comprise steep slopes, with numerous unloading cracks. On the surface, many medium to steeply dipping unloading fissures are seen that are parallel to the river. For instance, on the slope behind the Pearl Spring on the upstream right bank, about $1.8 \mathrm{~km}$ from the seismic dam near Hongshiyan, there is a long unloading crack (Fig. 13). It dips almost vertically, parallel to the bank, with a maximum opening width of about $15 \mathrm{~cm}$ (Fig. 13). Cut by this crack, the rock surrounding it is nearly separated from the slope, forming a dangerous rock mass that is $30-40 \mathrm{~m}$ high, $15 \mathrm{~m}$ wide and $5 \mathrm{~m}$ thick, with a volume of $3000 \mathrm{~m}^{3}$. Beneath this rock mass, thin beds of rock dip gently downstream. Gentle terrain appears below the steep slope, where the upper portion of the rock mass has partly broken off and is hanging (Fig. 13).

From observations to fissures on the surface of either bank of the river, the depth of the intense unloading zones is estimated to be over $50 \mathrm{~m}$. Such fissures and rock structure may jointly form unstable rock masses on the slope, which would become a favorable place for large-scale landsliding.

\section{Discussion on the formation mechanism of the landslide dam at Hongshiyan}

Khazai and Sitar's (2003) analysis of the Chi-Chi earthquake data suggest that only the very large catastrophic dip slope failures could be specifically tied to a particular geological setting. Keefer (1984) defined 14 types of landslides, primarily by material and character of movement, and indicated that weathered and intensely fractured rocks form rock avalanches. More detailed and specific studies indicate that faults, joints and fissures can control the rock avalanches'

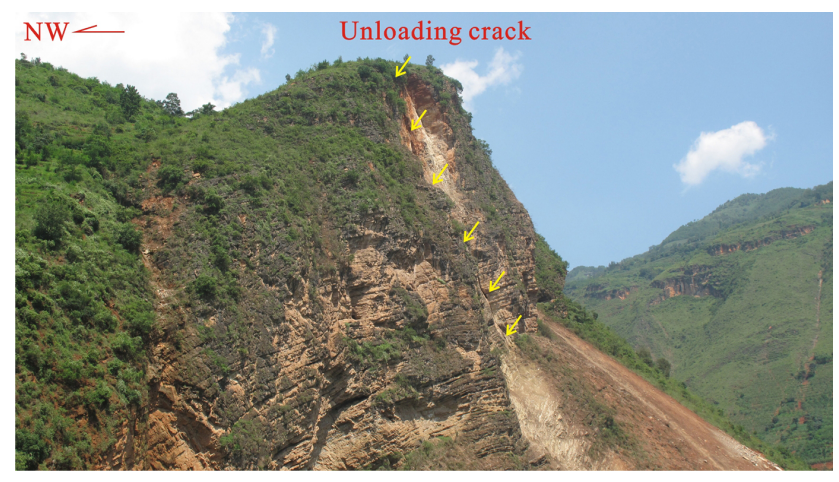

Figure 13. Unloading fissures (shown by yellow arrows) on the rear edge of slope at Pearl Spring.

occurrence since these faults or joints are potential planes for sliding or detachment (Sun and Cai, 1997; Hermanns and Strecker, 1999). During the 2008 Wenchuan earthquake, lots of large landslides may have occurred on pre-existing fractures or discontinuities that were undetectable prior to the earthquake at sites with fractured rocks (Qi et al., 2011; Chen et al., 2012). Based on an analysis of geology, geomorphology and lithology of slopes which are prone to large slope failures, unusually large landslides occur in settings with specific geological control. The formation of the big rock avalanche at Hongshiyan during the Ludian quake has three major stages as follows.

- Stage 1: under strong ground shaking, the joints parallel to and at normal angles to the river and unloading cracks (red bars in Fig. 14a) are opened and connected.

- Stage 2: the weak rock in the lower portion consisting of shale and mudstone is compressed, causing instability of the rock in the upper portion. Joints along beds (green line in Fig. 14b) develop further, resulting in rock masses that intersect each other. 


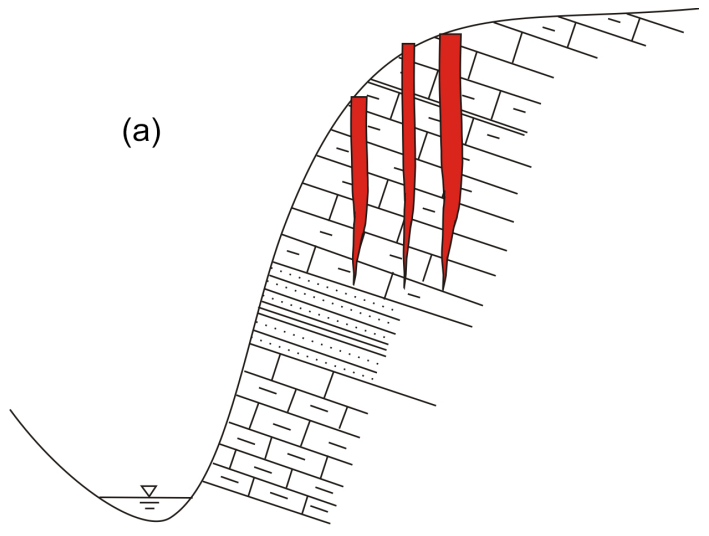

Of these stages, the first and second may proceed simultaneously, hardly being distinguishable. When the earthquake occurs, because of tensile stress at the slope, the first stage may be slightly ahead of the second one. And during the second stage, extensional split of vertical fissures happens from the beginning to the end.

\section{Conclusions}

The 3 August 2014 Ludian, China, $M_{\mathrm{s}}=6.5$ earthquake caused severe landslides. Of them the biggest one occurred at Hongshiyan near the epicenter, which was $10000 \times 10^{3} \mathrm{~m}^{3}$ in volume, clogging the Niulanjiang River, and creating a large dammed lake. Post-event field investigations yielded data on the following aspects: rock structure of landslides, lithology and geometry of the dam, composition and grain sizes of the debris avalanches. Based on these data, this work further analyzes the seismotectonic setting and geology and topography of the Hongshiyan area, and explores the mechanism for occurrence of such an unusual big landslide at this location. Our analysis suggests the following conditions are responsible for this catastrophic event.

1. Due to recent crustal deformation, intense incision in the river increased topographic relief with steep slopes and scarps, providing the essential pre-conditions for an enormous landslide.

2. Combined structures, including unloading fissures, high-angle joints and low-angle beds along the river, as well as upper-strong and lower-weak interlayer structure on the slopes, provide potential slide planes. The existence of weak layers in the slope is a factor critical to facilitating landsliding.

3. Hongshiyan is near an active fault. Intense crustal deformation resulted in rock fractures and weathering, providing major material sources for large-scale landslides. Frequent earthquakes might generate cumulative effects on the slope and reduce the strength of slope at this location, making it progressively more unstable through time.

Figure 14. Schematic diagram showing assumed forming process of the rock avalanche at Hongshiyan. Red bars show unloading cracks; green lines show joints along beds.

- Stage 3: rock masses lose stability, collapse, slide downward and move over a short distance along the sliding surface to the inside of the valley. This stage is a process of rapid motion as well as rock masses colliding with each other and fracturing. Thus it creates masses of varied sizes and powder-like piles, which block the river course, and coupled with the old landslide on the left bank, resulted in a dammed lake (Fig. 14c). 
Acknowledgements. This research was supported by the $\mathrm{Na}-$ tional Natural Science Foundation of China (grant no. 41472204 and 41572194). The authors would like to express thanks to Wang Kun for his help in the field investigation and providing the data of the Hongshiyan landslide dam. We are very grateful to the reviewers and the editor B. D. Malamud for their efforts to improve the manuscript.

Edited by: B. D. Malamud

Reviewed by: two anonymous referees

\section{References}

Allen, C. R., Luo, Z. L., Qian, H., Wen, X. Z., Zhou, H. W., and Huang, W. S.: Field study of a highly active fault zone: The Xianshuihe fault of southern China, Geol. Soc. Am. Bull., 103, 11781199, 1989.

Armijo, R., Tapponnier, P., Mercier, J., and Tong-Lin, H.: Late Cenozoic right-lateral strike-slip faulting in southern Tibet, J. Geophys. Res., 94, 2787-2838, 1989.

Chen, C. Y. and He, H. L.: Crust shortening of daliangshan tectonic zone in Cenozoic era and its implication, Seismol. Geol., 30, 443-453, 2008.

China Earthquake Administration: Earthquake Newsletter, available at: 20 May 2014, http://www.cea.gov.cn/publish/dizhenj/468/ 553/100821/index.html (last access: 24 January 2016], 2014.

Chen, X. L., Ran, H. L., and Yang, W. T.: Evaluation of factors controlling large earthquake-induced landslides by the Wenchuan earthquake, Nat. Hazards Earth Syst. Sci., 12, 3645-3657, doi:10.5194/nhess-12-3645-2012, 2012.

Division of Earthquake Prevention and Disaster Reduction, China Earthquake Administration: Catalogue of historical strong earthquakes in China (23rd century B.C. to 1911), Seismological Press, Beijing, 1995.

Geological and Mineral Bureau of Yunnan Province: Regional geological map of Yunnan Province, Geological Press, Beijing, 1990.

Guo, X. H., Wei, D. P., and Zhang, K. L.: GPS-constrained estimate method of present-day slip rate along major faults of SichuanYunnan region in China, J. Grad. Univ. Chinese Acad. Sci., 30, 74-82, 2013.

He, H. L., Ikeda, Y., He, Y. L., Togo, M., Chen, J., Chen, C. Y., Tajikara, M., Echigo, T., and Okada, S.: Newly generated Daliangshan Fault zone shortcutting on the Central segment of Xianshuihe-Xiaojiang Fault system, Sci. China Ser. D, 38, 564574, 2008.

Hermanns, R. L. and Strecker, M. R.: Structural and lithological controls on large Quaternary rock avalanches (sturzstroms) in arid northwestern Argentina, Geol. Soc. Am. Bull., 111, 934948, 1999.

Institute of Earthquake Engineering of Yunnan Province: Assessment report on seismic safety of the project site at the dammed lake on the Niulanjiang River nearby Hongshiyan, Yunnan Province, 2014.

Kan, R. J., Zhang, S. C., and Yan, F. T.: Discuss on modern tectonic stress field and the tectonic activity features in southern region, China, Chinese J. Geophys., 20, 96-109, 1977.
Keefer, D. K.: Landslides caused by earthquakes, Geol. Soc. Am. Bull., 95, 406-421, 1984.

Khazai, B. and Sitar, N.: Evaluation of factors controlling earthquake-induced landslides caused by Chi-Chi earthquake and comparison with the Northridge and Loma Prieta events, Eng. Geol., 71, 79-95, 2003.

Li, P.: The Xianshuihe-Xiaojiang fault zone, Earthquake Press, Beijing, 1993.

Li, P. and Wang, L. M.: Discuss on the basic characteristics of seismotectonics in Yunnan-Sichuan region, Chinese J. Geol., 4, 2837, 1975.

Meunier, P., Hovius, N., and Haines, J. A.: Regional patterns of earthquake-triggered landslides and their relation to ground motion, Geophys. Res. Lett., 34, L20408, doi:10.1029/2007GL031337, 2007.

Qi, S. W., Xu, Q., Zhang, B., Zhou, Y. D., Lan, H. X., and Li, L. H.: Source characteristics of long runout rock avalanches triggered by the 2008 Wenchuan earthquake, China, J. Asian Earth Sci., 40, 896-906, 2011.

Seismic intensity zoning group, State Seismological Bureau: Chinese seismic intensity zoning map, Seismological Press, Beijing, 1990.

Shen, X. H. and Xu, R. D.: Deformation characteristics and displacement amount of the Liangshan active Fault zone in late Cenozoic era, Seismol. Geol., 22, 232-238, 2000.

Song, F. M., Li, R. C., and Xu, X. W.: Preliminary results of the investigation of Paleo-earthquake along the Daliangshan Fault zone, Sichuan province, China, Seismol. Geol., 24, 27-34, 2002.

Sun, C. S. and Cai, H. W.: Developing and distributing characteristics of collapses and landslides during strong historic earthquake in China, J. Nat. Disast., 6, 25-30, 1997.

Tapponnier, P., Peltzer, G., and Armijo, R.: On the mechanics of the collision between India and Asia, in: Collision Tectonics, Geological Society London Special Publication 19, edited by: Coward, M. P. and Ries, A. C., Geological Society, London, 115-157, 1986.

Wei, Z. Y., He, H. L., Shi, F., Xu, Y. R., Bi, L. S., and Sun, H. Y.: Slip rate on the south segment of Daliangshan fault zone, Seismol. Geol., 34, 282-293, doi:10.3969/j.issn.0253-4967.2012.02.007, 2012.

Wen, X. Z., Du, F., Yi, G. X., Long, F., Fan, J., Yang, P. X., Xiong, R. W., Liu, X. X., and Liu, Q.: Earthquake potential of the Zhaotong and Lianfeng faults zones of the eastern Sichuan-Yunnan border region, Chinese J. Geophys., 56, 3361-3372, 2013.

Xu, X. W., Wen, X. Z., Zheng, R. Z., Ma, W. T., Song, F. M., and Yu, G. H.: Pattern of latest tectonic motion and dynamics of faulted blocks in Yunnan and Sichuan, Sci. China Ser. D, 33, 151-162, 2003.

Zhang, P. Z., Deng, Q. D., Zhang, G. M., Ma, J., Gan, W. J., Min, W., Mao, F. Y., and Wang, Q.: Active tectonic blocks and strong earthquakes in continental China, Sci. China Ser. D, 33, 12-20, 2003.

Zhang, P. Z., Shen, Z. K., Wang, M., Gan, W. J., Bürgmann, R., Molnar, P., Wang, Q., Niu, Z. J., Sun, J. Z., Wu, J. C., Sun, H. R., and You, X. Z.: Continuous deformation of the Tibetan Plateau from global positioning system data, Geology, 32, 809812, 2004.

Zhang, S. M., Nie, G. Z., Liu, X. D., Ren, J. J., and Su, G.: Kinematical and structural patterns of Yinjing-Mabian-Yanjin thrust 
fault zone, Southeast of Tibet plateau and its segmentation from earthquakes, Seismol. Geol., 27, 221-233, 2005.

Zhong, D. L. and Ding, L.: Rising process of the Qinghai-Xizang (Tibet) Plateau and its mechanism, Sci. China Ser. D, 26, 289295, 1996.
Zhou, R. J., Li, X. G., Huang, Z. Z., He, Y. L., and Ge, T. Y.: Average slip rate of Daliang mountains fault zone in Sichuan in late Quaternary period, J. Seismol. Res., 26, 191-196, 2003. 